\title{
Special issue on critical French citizenship
}

\author{
Martial Foucault ${ }^{1}$
}

Published online: 7 November 2019

(c) Springer Nature Limited 2019

\begin{abstract}
This special issue engages with the "cultural backlash hypothesis"- that citizens dissatisfied with democratic regimes tend to support the emergence of non representative democracy. The first article challenges classical notions of citizenship and shows that critical citizens actually call for more competent representatives. The second piece asserts that critical citizenship is more complex than what previous research has shown and that only certain types of citizenship are more likely to result in protest votes. As the introduction points out, the two pieces together paint a far more complex picture of citizenship than previously understood through an innovative approach that combines normative political theory with survey research in a country setting. A new research agenda that comes out of these findings is also proposed.
\end{abstract}

Keywords Critical citizenship · Survey $\cdot$ Populism · Citizenship · Illiberal democracy

\section{Introduction}

\section{Martial Foucault (Sciences Po, CEVIPOF)}

As associate editor, I am very honoured to introduce this special issue on critical citizenship for three main reasons. The first is as a testimony to my colleague and friend, Professor Robert Elgie, who initiated the French Politics journal and tragically passed away last July. During the several years I worked with him, I learned a great deal on how to make French Politics more visible and a "must read" for a new generation of political scientists focusing on French politics. Among the many tasks expected from an associate editor such as identifying, convincing and encouraging scholars to publish original manuscripts, I fulfilled one of his wishes by encouraging

Martial Foucault

martial.foucault@sciencespo.fr

1 Sciences Po, Political Science, CEVIPOF, 98, rue de l'université, 75007 Paris, France 
my colleagues at Sciences Po to submit their work on an issue of primary importance: critical citizenship.

The second reason is the topic. A countless number of articles, books, workshops and round tables on dissatisfaction with democracy have been written over the past decade or so. The latest book by Inglehart and Norris (2019) shows how citizens who are dissatisfied with the democratic regimes they live in are likely to force such regimes to envisage other forms of democracy (direct, deliberative, participatory among others). Alongside this idea, the cultural backlash hypothesis offers some insightful perspectives on the rise of illiberal aspirations in today's democracies. The main argument of this hypothesis rests on a demographic anomaly, i.e. that older citizens can be held accountable for such a populist rise because they are in fear of traditional cultural values being lost as a result of multiculturalism and successive waves of immigration. However, such an explanation remains contested on empirical grounds as demonstrated by Algan et al. (2019).

The third reason is methodological in nature. In this special issue, both papers make a substantive effort to combine together political theory's foundations of citizenship and empirical survey-based evidence. A number of unexpected results prove that public opinion data continue to provide a rich terrain for the improvement in our knowledge of forms of critical citizenship in a variety of political contexts.

\section{Mapping critical citizens}

As initially conjectured by Norris (1999),

The twentieth century has therefore experienced periodic cycles of hope and fear about the state of popular support for democratic government. If we establish a similar pattern of growing scepticism about government across established democracies, then plausibly this may be due to common structural and secular trends shaping public opinion in advanced industrialised societies.

Twenty years later, contemporary democracies are suffering from ever-increasing levels of dissatisfaction among citizens, ranging from political distrust to political disaffection. However, at the same time, the exit option from a Hirschmannian perspective is in competition with the voice option. This means that a large number of dissatisfied citizens continue to maintain a positive lens on the functioning of democracy. As Doorenspleet (2012) points out, critical citizens are not only critical, dissatisfied democrats, but also well-informed, interested and involved stakeholders who focus on improving the way in which the political system they live in functions.

Investigating two conflicting dimensions of political representation, i.e. random selection (bottom-up process) versus skills-testing of representatives (top-down process), David Copello achieves a substantial outcome in the French context. Indeed, the classical view of the virtues of sortition does not necessarily contradict the call for more experts to become elected representatives, and for more elected representatives to become experts. Such a result provides an intriguing and fascinating paradox that might be formulated in the following way: while random selection appears to be 
an uncontested tool to ensure better representation, citizens also call for more competent representatives that current electoral institutions (such as electoral systems) do not allow for.

In the same vein, but adopting a more normative approach, Janie Pelabay and Rejane Senac demonstrate empirically that individual French political preferences on democracy yield four types of citizen: non-critical citizens, demo-reformers, demo-transformers and demo-exiters. Moving beyond an overly simplistic and binary understanding of satisfaction with democracy (for or against), the authors convincingly argue that French critical citizens are multi-facetted. Focusing on a number of individual characteristics to disentangle the four categories of citizen, they show that partisan identification, ideological proximity and socio-demographic variables are of the utmost importance. This significant result offers a complementary response to the way in which certain styles of critical citizenship (especially among demo-transformers and demo-exiters) are more likely to result in protest votes and-in France-in a populist far-right vote.

\section{Conclusion}

Both papers emphasise the complexity of a theoretical definition of critical citizens alone, as such an approach does not necessarily correspond to the empirical evidence. This is the main advantage of using surveys to identify a new method to capture the different dimensions of critical citizenship. It is clear that protest movements in France ("the Yellow Vests"), in Hong-Kong, in the UK, in Venezuela and in Catalonia share a feeling that they have been betrayed by their representatives, albeit for different reasons. However, they do differ in their vision about how to achieve a more consistent democratic regime. Contrary to what is regularly advocated by protesters, it is not representative democracy as a regime that is in crisis, but rather existing practices within such a regime. For that reason, this special issue adopts an empirical approach to open the black box of multi-dimensional representations of the "demos" and the "kratos."

In addition, although not at the heart of either of these papers, the analysis of critical citizenship may reveal other aspects of satisfaction with democracy depending on whether the approach is liberal or republican. Indeed, social and political tensions around the world do reveal that social and individual representations of rights, justice, political values, etc. may to some extent be orthogonal to actual practice by elected officials. As a research agenda, the next step should be the pursuit of this innovative investigation to conceive of a "survey module" which should be replicated in other contexts. This would ensure that political scientists and political philosophers were in a position to encourage other social science scholars to include the influence of critical citizens' political representations on dissatisfaction with democracy in their explanatory models 


\section{References}

Algan, Y., E. Beasley, D. Cohen, and M. Foucault. 2019. Les origines du populisme. Histoire d'un schisme politique et social. Paris: Le Seuil.

Doorenspleet, R. 2012. Critical citizens, democratic support and satisfaction in African democracies. International Political Science Review 33 (3): 279-300.

Inglehart, R., and P. Norris. 2019. Cultural backlash: Trump, Brexit, and authoritarian populism. Cambridge: Cambridge University Press.

Norris, P. 1999. Critical citizens: global support for democratic government. Oxford: Oxford University Press.

Publisher's Note Springer Nature remains neutral with regard to jurisdictional claims in published maps and institutional affiliations. 